\title{
Perubahan Jumlah CD4 Setelah Enam Bulan Pertama Terapi Antiretroviral di RSPI Prof. Dr. Sulianti Saroso
}

\author{
The Changes in CD4 After the First Six Months of Antiretroviral Therapy at Sulianti Saroso \\ Infectious Disease Hospital
}

\author{
Sri Rahayuni ${ }^{1,2}$, Nina Mariana1, Buchori Lapau ${ }^{2}$, Evy Nurvidiya Arifin ${ }^{2}$, Siti Maemun ${ }^{1}$ \\ ${ }^{1}$ RSPI Prof Dr. Sulianti Saroso, ${ }^{2}$ Program Pasca sarjana IImu Kesehatan Masyarakat Universitas \\ Respati Indonesia
}

Korespodensi Penulis:

Sri Rahayuni

Email :kenik_srirahayuni@ymail.com

\begin{abstract}
Abstrak
Latar belakang: Pemberian ARV dapat mengoptimalkan outcome klinis ODHA. Di Indonesia, informasi tentang efek terapi ARV setelah 6 bulan pertama terhadap perubahan jumlah CD4 masih terbatas. Penelitian bertujuan mengidentifikasi perubahan jumlah CD4 setelah 6 bulan pertama pemberian jenis ARV Kombinasi Obat Terpisah (KOT) dan Kombinasi Dosis Tetap (KDT) di RSPI Prof. Dr. Sulianti Saroso periode Januari 2014-Maret 2017. Metode: Desain penelitian adalah kohort retrospektif, jumlah sampel 154, terdiri dari 87 ODHA yang mendapatkan KOT dan 87 KDT. Pengambilan sampel secara consecutive sampling dengan sumber data rekam medis. Setelah data terkumpul, dilakukan analisis univariat, bivariat menggunakan uji Chi Square, dan multivariat dengan regresi logistik. Hasil: Dari 87 yang mendapatkan KOT, $26(29,9 \%)$ CD4 menurun/tetap dan $61(70,1 \%)$ meningkat. Sedangkan yang mendapatkan KDT, $3(3,4 \%)$ CD4 menurun/tetap dan $84(96,6 \%)$ meningkat. Pada ODHA yang adherence juga mengalami peningkatan CD4. Ada hubungan yang bermakna pemberian jenis ARV dan adherence dengan perubahan CD4 $(p<0,05)$. Risiko penurunan CD4/tetap 11 kali lebih tinggi pada ODHA yang mendapatkan KOT daripada KDT (95\%Cl=2,98-41,61), sedangkan risiko penurunan CD4/tetap 6 kali lebih tinggi pada ODHA yang tidak adherence $(95 \% \mathrm{Cl}=2,10$ 16,14). Kesimpulan: Perubahan jumlah CD4 dipengaruhi oleh penggunaan ARV KOT atau KDT dan juga adherence.
\end{abstract}

Kata kunci: CD4, terapi antiretroviral,

\begin{abstract}
Background: : Antiretroviral therapy has improved clinical outcomes of patients with HIVIAIDS (PLWHA). In, information about the effect of ARV therapy after the first 6 months on the changed CD4 count is still limited. This research aims to determine the changes in CD4 counts after the first 6 months of a once daily fixed-dose combination (FDC) and free combination antiretroviral therapy at RSPI Prof. Dr. Sulianti Saroso, during the period of January 2014-March 2017. Method: The design of the study is retrospective cohort, with a total of 154 samples consisting of 87 PLWHA who received a free combination of ARV and 87 PLWHA who received FDC. Samples were selectedusingthe consecutive sampling technique with medical records as the source of data. After the data were collected, analyses were carried out, namely the univariate analysis, bivariate analysis using a chi-square test, and multivariate analysis using the logistic regression. Result: Of the 87 who received a free combination of ARV, 26 (29.9\%) had a decreased/unchanged CD4 count and 61 (70.1\%) had an increased CD4 count. Meanwhile, of those who received FDC, $3(3.4 \%)$ had a decreased/unchanged CD4 count and 84 (96.6\%) had an increased CD4 count. PLWHA withgood adherence also experienced an increase in the amount of CD4 cells. There was a significant relation of the type of ARV drugs administered and adherence to changes in CD4 counts $(p<0.05)$. The risk of a decreased/unchanged CD4 counts 11 times higher in PLWHA who received a free combination of ARV than those who received $F D C(95 \% \mathrm{Cl}=2.98$ 41.61), while the risk of a decreased/unchanged CD4 counts 6 times higher in PLWHA who had adherence problems $(95 \% \mathrm{Cl}=2.10-16.14)$. Conclusion: the changes in CD4 counts were affected by FDC or free combination antiretroviral use and also adherence.
\end{abstract}

Keywords: CD4, antiretroviral therapy

The Indonesian Journal of Infectious Diseases | Volume 4 No. 1 


\section{Pendahuluan}

Infeksi Human Immunodeficiency Virus (HIV) menyebabkan Acquired Immune Deficiency Syndrome (AIDS), hal ini mulai dikenal pada tahun 1981.(1) Sejak virus ini ditemukan, 78 juta orang terinfeksi HIV dan hampir 39 juta meninggal karenanya.. Menurut Badan Kesehatan Dunia (WHO), peduduk dunia yang terinfeksi HIV mencapai 35 juta, dan 2,1 juta diantaranya adalah kasus baru dengan 1,5 juta kematian karena AIDS.(2) Jumlah kasus tertinggi di Afrika, disusul Asia dan Amerika Serikat. ${ }^{(1)}$ Di Indonesia, jumlah kumulatif kasus HIV dari tahun 1987 sampai dengan Maret 2017 dilaporkan sebanyak 242.699, tertinggi di Provinsi DKI Jakarta (46.758), sedangkan jumlah kumulatif AIDS dalam kurun waktu yang sama sebanyak $87.453 .{ }^{(3)}$

Virus HIV menyerang sel darah putih terutama limfosit sub jenis $\mathrm{T}$ helper atau yang disebut juga sebagai Clusters of Differentiation 4 (CD4). Virus HIV menyerang CD4, dan dijadikan sebagai tempat perkembangbiakan, kemudian merusak sel tersebut. ${ }^{(4)}$ Jumlah CD4 merupakan indikator yang sangat penting dalam penentuan tingkat kekebalan tubuh dan efek terapi antiretroviral (ARV). Batas normal CD4 yaitu $500-1000 \mathrm{sel} / \mathrm{mm}^{3}$, dimana tubuh mampu mempertahankan diri dari komplikasi, khususnya dalam pencegahan Infeksi Oportunistik (IO).

Sejak ditemukannya ARV tahun 1996, morbiditas dan mortalitas akibat HIV menurun secara signifikan. Angka kematian Orang dengan HIV/AIDS (ODHA) baik pada anak maupun dewasa menurun sekitar $29 \%$ sejak 2005 . Jumlah kematian HIV/AIDS di Amerika latin bahkan menurun 37\% dalam dekade terakhir. ${ }^{(5,6)}$

terapi ARV tidak menyembuhkan, namun dapat menekan replikasi virus HIV hingga tingkat minimum dan menurunkan kejadian infeksi oportunistik dan risiko kematian. Antiretroviral selain mampu menekan replikasi virus untuk menunda timbulnya AIDS, juga secara signifikan meningkatkan kualitas hidup serta memperpanjang harapan hidup ODHA. Dengan adanya penekanan replikasi virus secara efektif, maka diharapkan dapat meminimalkan timbulnya resistensi virus terhadap obat dan memperlambat progresivitas penyakit. $^{(7)}$

Kepatuhan minum obat ARV (Adherence) merupakan salah satu cara untuk mendapatkan dosis yang efektif menekan replikasi virus sekaligus mengurangi kejadian resistensi dan mutasi virus. Adherence merupakan 
faktor yang dapat diubah terkait pengetahuan, sikap, dan perilaku ODHA dalam minum ARV serta keterlibatan Pengawas Minum Obat (PMO), seperti keluarga atau orang terdekat ODHA dengan melakukan kontrol yang terdokumentasi menggunakan form monitoring, sehingga berbasis bukti.

.Ketidakpatuhan minum obat salah satunya dipengaruhi oleh kombinasi obat ARV yang tersedia di fasilitas kesehatan. Kombinasi Obat Terpisah (KOT) yang terdiri dari beberapa sediaan (tablet), yaitu kombinasi Zidovudin/Tenofovir + Lamivudin/emtricitabin + Efavirenz/ Nevirapin, menjadi salah satu alasan ODHA tidak minum obat secara teratur, apalagi bila ODHA mendapat tambahan obat untuk penyakit penyerta. Oleh karena itu, ARV Kombinasi Dosis Tetap (KDT) yang terdiri dari 3 obat (Tenovofir + Lamivudine + Efavirenz) dalam satu tablet perhari sangat penting dalam meningkatkan kepatuhan ODHA yang harus minum obat secara terus-menerus dalam jangka waktu yang panjang (seumur hidup). Jenis ARV KDT ini sudah tersedia di Indonesia sejak tahun 2013. . $^{(7,8)}$

Untuk memastikan respon terapi ARV pada penggunaan KOT dan KDT, maka diperlukan penilaian klinis, imunologis dan virologis Secara umum monitoring klinis dilakukan pada minggu ke-2, 4, 12 dan 24 sejak dimulainya terapi ARV. Monitoring perbaikan imunologi (jumlah CD4) dan virologi (viral load) umumnya dilakukan setelah 6 bulan atau lebih sering apabila ada indikasi klinis. ${ }^{(9)}$ Informasi tentang efek pemberian ARV setelah 6 bulan pertama terapi terhadap perubahan jumlah CD4 masih terbatas di Indonesia, khususnya di Rumah Sakit Penyakit Infeksi (RSPI) Prof. Dr. Sulianti Saroso. Oleh karena itu penelitian ini bertujuan mengidentifikasi perubahan CD4 (menurun/tetap atau meningkat) setelah 6 bulan pertama pemberian jenis ARV KOT dan KDT di RSPI Prof. Dr. Sulianti Saroso selama periode Januari 2014-Maret 2017.

\section{Metode}

Desain penelitian adalah kohort retrospektif, dengan sumber data rekam medis di RS. Pengambilan sampel dilakukan secara consecutive sampling, yaitu pemilihan sampel dengan menetapkan subjek yang memenuhi kriteria inklusi sampai kurun waktu tertentu, sehingga jumlah subyek yang diperlukan terpenuhi. Kriteria inklusi penelitian adalah orang dengan HIV/AIDS (ODHA) yang baru mendapat terapi ARV (KOT atau KDT) selama 6 bulan pengamatan, periode Januari 
2014-Maret 2017. Setelah 6 bulan, dilakukan pemeriksan ulang CD4. Dikatakan meningkat apabila hasil hitung atau jumlah CD4 lebih tinggi dibandingkan CD4 sebelum terapi, sebaliknya dikatakan menurun/tetap apabila jumlah CD4 lebih rendah atau sama dengan CD4 sebelum terapi. Besar sampel penelitian, masing-masing sebanyak 87 untuk kelompok KOT dan KDT. Variabel yang diteliti terdiri dari 9 variabel, yaitu perubahan jumlah CD4 (dependen), serta terapi ARV (KOT/KDT), adherence (kepatuhan terhadap terapi ARV), komorbid IO, stadium klinis HIV/AIDS, cara penularan, usia, jenis kelamin, dan tingkat pendidikan ODHA (indepeden). Setelah data terkumpul, dilakukan analisis univariate ,bivariat menggunakan uji Chi Square dan multivariat dengan regresi logistik metode enter.

\section{Hasil}

Tabel 1. Distribusi frekuensi ODHA menurut variabel independen dan perubahan CD4

\begin{tabular}{|c|c|c|c|c|c|c|}
\hline \multirow{3}{*}{ Variabel independen } & \multicolumn{4}{|c|}{$\begin{array}{l}\text { Perubahan CD4 } \\
\end{array}$} & \multirow{2}{*}{\multicolumn{2}{|c|}{ Total }} \\
\hline & \multicolumn{2}{|c|}{ Menurun/tetap } & \multicolumn{2}{|c|}{ Meningkat } & & \\
\hline & $\mathrm{n}$ & $\%$ & $\mathbf{n}$ & $\%$ & \multicolumn{2}{|c|}{ n $\%$} \\
\hline \multicolumn{7}{|l|}{ Terapi ARV } \\
\hline KOT & 26 & 29,9 & 61 & 70,1 & 87 & 100 \\
\hline KDT & 3 & 3,4 & 84 & 96,6 & 87 & 100 \\
\hline \multicolumn{7}{|l|}{ Adherence ARV } \\
\hline Tidak adherence & 14 & 50,0 & 14 & 50,0 & 28 & 100 \\
\hline Adherence & 15 & 10,3 & 31 & 89,7 & 46 & 100 \\
\hline \multicolumn{7}{|l|}{ Komorbid IO } \\
\hline Ada 10 & 9 & 14,3 & 54 & 85,7 & 63 & 100 \\
\hline Tidak ada IO & 20 & 18,0 & 91 & 82,0 & 11 & 100 \\
\hline \multicolumn{7}{|l|}{ Stadium klinis HIV/AIDS } \\
\hline Stadium Klinis 3 atau 4 & 4 & 10,0 & 36 & 90,0 & 40 & 100 \\
\hline Stadium klinis 1 atau 2 & 25 & 18,7 & 09 & 81,3 & 134 & 100 \\
\hline \multicolumn{7}{|l|}{ Cara penularan } \\
\hline IDU $^{*}$ & 1 & 11,1 & 8 & 88,9 & 9 & 100 \\
\hline Bukan IDU & 28 & 17,0 & 37 & 83,0 & 165 & 100 \\
\hline \multicolumn{7}{|l|}{ Usia (tahun) } \\
\hline$>40$ tahun & 6 & 26,1 & 17 & 73,9 & 23 & 100 \\
\hline$\leq 40$ tahun & 23 & 15,2 & 28 & 84,8 & 151 & 100 \\
\hline \multicolumn{7}{|l|}{ Jenis kelamin } \\
\hline Perempuan & 3 & 13,0 & 20 & 87,0 & 23 & 100 \\
\hline & 26 & 17,2 & 25 & 82,8 & 151 & 100 \\
\hline \multicolumn{7}{|l|}{ Tingkat pendidikan } \\
\hline$\leq$ SLTA/sederajat & 12 & 16,9 & 59 & 83,1 & 71 & 100 \\
\hline$>$ SLTA/sederajat & 17 & 16,5 & 86 & 83,5 & 103 & 100 \\
\hline
\end{tabular}

Berdasarkan paparan pada tabel 1 meningkat pada kelompok KOT sebesar dari 87 ODHA terdapat perubahan CD4 70,1\% dan KDT sebesar 96,6\%. Pada The Indonesian Journal of Infectious Diseases | Volume 4 No. 1 
ODHA yang tidak adherence ARV, didapatkan persentase perubahan CD4 menurun/tetap dan meningkat sama, sedangkan yang adherence, didapatkan perubahan CD4 menurun/tetap sebesar $10,3 \%$ dan meningkat sebesar $89,7 \%$.

Pada tabel 2 terlihat ada hubungan yang bermakna antara jenis terapi ARV
(KOT/KDT) dan adherence terhadap hasil hitung CD4 yang menurun/tetap $(p<0,05)$. Tidak ada hubungan bermakna antara komorbid IO, stadium klinis HIV/AIDS, cara penularan, usia, jenis kelamin, dan tingkat pendidikan dengan hasil CD4 yang menurun/tetap.

Tabel 2. Analisis bivariat variabel yang mempengaruhi perubahan CD4.

\begin{tabular}{llcc}
\hline Variabel independen & $\boldsymbol{P}_{\text {-value }}^{*}$ & OR & $\mathbf{9 5 \%} \mathbf{C l}$ \\
\hline Terapi ARV (KOT/KDT) & 0,000 & 11,93 & $3,46-41,23$ \\
Adherence ARV & 0,000 & 8,73 & $3,50-21,77$ \\
Komorbid IO & 0,672 & 0,76 & $0,32-1,78$ \\
Stadium klinis HIV/AIDS & 0,295 & 0,48 & $0,16-1,49$ \\
Cara penularan & 1,000 & 0,61 & $0,07-5,09$ \\
Usia & 0,228 & 1,96 & $0,70-5,51$ \\
Jenis kelamin & 0,770 & 0,72 & $0,20-2,61$ \\
Tingkat pendidikan & 1,000 & 1,03 & $0,46-2,31$ \\
\hline
\end{tabular}

${ }^{*} \mathrm{p}$ dengan Chi Square

Tabel 3. Analisis multivariat variabel yang mempengaruhi perubahan CD4

\begin{tabular}{llcl}
\hline Variabel independen & P-value & OR & 95\%Cl \\
\hline Terapi ARV (KOT/KDT) & 0,000 & 11,14 & $2,98-41,62$ \\
Adherence ARV & 0,001 & 5,82 & $2,09-16,14$ \\
Komorbid IO & 0,165 & 0,40 & $0,11-1,46$ \\
Stadium Klinis & 0,487 & 0,58 & $0,12-2,73$ \\
Usia & 0,188 & 2,33 & $0,66-8,23$ \\
\hline
\end{tabular}

Hasil analisis multivariat menunjukkan bahwa variabel paling dominan yang mempengaruhi jumlah CD4 menurun /tetap setelah 6 bulan pertama terapi adalah jenis ARV (KOT/KDT). Risiko terjadinya penurunan CD4/tetap yaitu 11 kali lebih tinggi pada ODHA yang mendapat KOT daripada yang mendapat KDT $(95 \% \mathrm{Cl}=2,98-41,62)$, sedangkan risiko penurunan CD4/tetap 6 kali lebih tinggi pada ODHA yang tidak adherence ARV daripada yang adherence $(95 \% \mathrm{Cl}=2,09-16,14)$.

\section{Pembahasan}

Penggunaan terapi ARV (KDT/KOT) dan kepatuhan (adherence) minum obat ARV dapat meningkatkan CD4. Hasil penelitian menunjukkan peningkatan yang bermakna dari CD4 pada kedua 
kelompok tersebut. Peningkatan CD4 setelah terapi ARV disebabkan karena adanya perbaikan fungsi kelenjar timus. Kelenjar timus mempunyai fungsi yang penting dalam sistem kekebalan tubuh. Gangguan fungsi kelenjar ini biasanya terjadi pada stadium klinis awal infeksi HIV, dan ketika kerusakan sudah mulai terjadi, maka sangat sulit diperbaiki. ${ }^{(10)}$

Pada ODHA yang mendapat KOT, risiko CD4 menurun/tetap setelah 6 bulan terapi, 11 kali lebih tinggi daripada yang mendapat KDT $(95 \% \mathrm{Cl}=2,98-41,62)$, sedangkan pada ODHA yang tidak adherence, risiko mengalami CD4 menurun/tetap 6 kali lebih tinggi daripada yang adherence $(95 \% \mathrm{Cl}=2,10-16,14)$.

Rejimen ARV KOT yang terdiri dari beberapa tablet menjadi salah satu alasan ODHA tidak minum obat secara teratur. Pemberian ARV KOT yang lebih dari satu tablet per hari, kemungkinan ODHA tidak minum obat karena lupa atau alasan lainnya lebih tinggi bila dibandingkan dengan KDT yang hanya satu tablet per hari. Oleh karena itu dapat digaris bawahi bahwa adanya risiko terapi ARV KOT terhadap jumlah CD4 yang menurun/tetap bukan berarti obat ARV KOT itu sendiri tidak efektif, melainkan karena secara tidak langsung ada hubungannya dengan tidak adherence ARV. Pemberian ARV KDT dalam bentuk satu tablet perhari merupakan salah satu solusi dalam permasalahan tersebut, walaupun dalam penelitian ini tidak dapat dihubungkan secara langsung antara variabel adherance ARV dengan ODHA yang mendapat KOT atau KDT.

Hasil penelitian ini berbeda dengan penelitian Mariana, dkk bahwa dari seluruh ODHA baik yang menggunakan KOT maupun KDT mempunyai adherence dan manfaat terapi yang sama terhadap perbaikan status imunologi dan virologi ODHA. ${ }^{(11)}$ Adapun perbedaan hasil pada kedua penelitian ini karena kriteria yang digunakan untuk ODHA yang mendapat KOT/KDT tidak sama. Pada penelitian Mariana, dkk KOT yang digunakan hanya berbasis Tenovofir (NRTI) dan Efavirenz (NNRTI), sedangkan pada penelitian ini KOT yang digunakan semua kombinasi Zidovudin/Tenofovir/ Stavudin + Lamivudin/Emtricitabin (NRTI) dan Efavirenz/Nevirapin (NNRTI).

Keterbatasan penelitian ini adalah pengamatan terhadap variabel komorbid IO, stadium klinis, dan usia hanya dilakukan sekali pada awal penelitian. Selain itu, kriteria ODHA yang menggunakan KOT dan KDT tidak sebanding. 


\section{Kesimpulan}

Perubahan jumlah CD4 (menurun/ tetap atau meningkat) setelah 6 bulan pertama terapi ARV dipengaruhi oleh kombinasi ARV yang diberikan (KOT/KDT) dan adherence ARV.

\section{Saran}

Rumah sakit bekerja sama dengan kelompok dukungan sebaya membuat program dan jadwal pendidikan kesehatan kepada ODHA secara konsisten tentang perilaku hidup bersih dan sehat, menggunakan alat pelindung diri saat di keramaian (menggunakan masker) dan mengkonsumsi makanan dengan gizi seimbang. Selain itu kontinu dalam pelayanan konseling untuk memantau adherence/ kepatuhan ARV terutama bagi odha dengan tingkat adherence/kepatuhan ARV yang rendah.

\section{Ucapan Terima Kasih}

Ucapan terima kasih kepada Direktur Utama RSPI Prof. Dr. Sulianti Saroso beserta jajarannya yang telah membantu pelaksanaan penelitian.

\section{Daftar Pustaka}

1. Sumantri R, Wicaksana $R$, Ariantana AR. Prevalensi dan Faktor Risiko Anemia pada HIV-AIDS Prevalence and Risk Factors of Anemia in HIV-
AIDS. Mkb. 2008;41(38):2-8.

2. World Health Organization (WHO). Tuberculosis and HIV. 2015.

3. Kementerian Kesehatan RI. Laporan perkembangan HIV-AIDS \& penyakit infeksi menular seksual (PIMS) triwulan I Tahun 2017. Jakarta; 2017.

4. Djoerban Z. HIV/AIDS di Indonesia. Dalam: Buku Ajar Ilmu Penyakit Dalam. Jilid III, Edisi V. Jakarta: Pusat Penerbit Departemen IImu Penyakit Dalam FKUI; 2009.

5. Centers for Disease Control and Prevention. HIV Surveillance Report, 2009 [Internet]. Aids. 2009 [cited 2018 Mar 1]. Available from: http://www.cdc.gov/hiv/topics/surveill ance/resources/reports/

6. Mariana N, Rusli A. Efavirenz Plasma Concentrations and HIV Viral Load in HIV / AIDS-tuberculosis Infection Patients Treated with Rifampicin. Acta Med Indones. 2016;48(1):10-6.

7. Velvanathan $T$, Islahudin $F$, Sim BLH, Taha NA. Simplification of HAART therapy on ambulatory HIV patients in Malaysia: A randomized controlled trial. Pharm Pract (Granada). 2016;14(4):1-7.

8. Ramjan R, Calmy A, Vitoria M, Mills EJ, Hill A, Cooke G, et al. Systematic review and meta-analysis: Patient 
and programme impact of fixed-dose combination antiretroviral therapy. Trop Med Int Heal [Internet]. 2014;19(5):501-13. Available from: http://doi.wiley.com/10.1111/tmi.1229 7

9. Kementerian Kesehatan RI. Pedoman Pengobatan Antiretroviral. In Jakarta: Direktorat Jenderal P2P; 2014.

10. Sun Y, Fu Y, Zhang Z, Tang T, Liu J, Ding $\mathrm{H}$, et al. The investigation of CD4+T-cell functions in primary HIV infection with antiretroviral therapy. Medicine (Baltimore) [Internet]. 2017 Jul [cited 2018 Jan 17];96(28):e7430. Available from: http://www.ncbi.nlm. nih.gov/pubmed/28700479

11. Mariana N, Lisdawati V, Maemun S, Sucahyo A, Debby P, Yuli, et al. Evaluation of Adherence, Virology and Imunology Response in HIV Patients Treated with a Once Daily Fixed Dose Combination (FDC) and a Free Combination of Antiretroviral. Adv Sci Lett [Internet]. 2018 Aug 1 [cited 2018 Sep 17];24(8):6143-6. Available from: http://www. ingentaconnect.com/content/10.1166 lasl.2018.12656 